\title{
Green economy in the wastewater treatment sector: Jobs, awareness, barriers, and opportunities in selected local governments in South Africa
}

\author{
Benton Otieno*, Aoyi Ochieng \\ Centre for Renewable Energy and Water, Vaal University of Technology, Private Bag X021, \\ Vanderbijlpark, South Africa
}

\begin{abstract}
The green economy (GE) has increasingly gained international focus, with new strategies aimed at restructuring the economy in an environmentally friendly manner. A study was carried out to analyse existing and potential green jobs and identify green qualifications and skills necessary for the development of the GE. The study was done within the context of the role of local governments in the adoption of green economy strategies in the wastewater treatment sector, in selected local governments across the northern provinces of South Africa. A descriptive survey method with qualitative and quantitative approaches was employed for data collection from twenty-four wastewater treatment plants in eleven local municipalities. The concept of the GE was foreign to several employees, who could not identify green jobs within most sectors of the economy. Only $13.5 \%$ of the employees of the surveyed plants were involved in directly green jobs. A further $36 \%$
\end{abstract}

were in green-related jobs while the remaining $50.5 \%$ were involved in non-green jobs. Barriers to the creation of green jobs and implementation of green practices were the shortage of employees with green and conventional wastewater treatment skills, and lack of training in green skills. Several opportunities for green jobs creation exist, such as the implementation of renewable energy, re-use of treated effluent, and processing of waste sludge into compost. To spur GE growth and create green jobs, the creation of awareness, development of skills and implementation of green technologies should be intensified.

Keywords: local government, green jobs, Northern Cape, North West, South Africa

Journal of Energy in Southern Africa 29(1): 50-58

DOI: http://dx.doi.org/10.17159/2413-3051/2018/v29i1a3379

Published by the Energy Research Centre, University of Cape Town ISSN: 2413-3051 http://journals.assaf.org.za/jesa

Sponsored by the Department of Science and Technology

\footnotetext{
* Corresponding author:

Email: bentononynango@gmail.com
} 


\section{Introduction}

The increased amount of domestic and industrial wastes, greenhouse gas emissions, and shortages in energy supply are major threats faced by several countries. These issues have a major impact on the environment, as they cause pollution leading to environmental degradation and climate change. Pollution has created an urgent need for alternative resources and processes to control, reduce or, if possible, eliminate the effects on the environment. Many communities are promoting the culture of recycling, reuse, reduction of waste, and energy conservation. These alternatives fall under the initiative called the green economy (GE). The GE conceptually refers to improved human well-being and social equity, and reduced environmental risk and ecological scarcities (Karakul, 2016; Musango et al., 2014; Topgül, 2015). The GE concept, coined at the United Nations Conference on Sustainable Development $($ Rio +20$)$ is seen by several international organizations, including the World Bank, as a means to sustainability (Loiseau et al., 2016; Bek et al., 2017). The GE is invariably driven by green technology, for which the objective is to improve the quality of life in a sustainable way for the present and future generations (Lyon et al., 2017; Cai et al., 2015). The GE is viewed as a route to sustainable development, given its potential to address inclusive interdependence among social protection, economic revival, and natural systems. Moreover, the GE has the potential to accelerate economic growth with the creation of green jobs (Kaggwa et al., 2013; Death, 2011).

A green job is any work in sectors such as manufacturing, agriculture, administrative, research and development, and service delivery that promotes preserving or restoring environmental quality. Green jobs include those that are aimed at protecting the environment, energy reduction through high efficiencies, economy de-carbonisation, and reduction or elimination of pollution and waste generation (Yi, 2013; Consoli et al., 2016). A growing number of green jobs will be created as countries transform businesses towards the GE, with green innovative companies and regions more likely to lead in the creation and retention of green jobs. Green jobs creation and greening of existing nongreen jobs are indispensable means for attaining development that is sustainable and providing decent work for all. With proper design and management, green jobs can foster gender equality and social inclusion, and eradicate poverty in several countries including South Africa (Kaggwa et al. 2013).

South Africa is faced with several challenges, including high unemployment and significant differences in the welfare and income of employees (Winkler and Marquand, 2009; Shava and Tafadzwa, 2016). Further, South Africa is more energy- intensive than its international peers, and its greenhouse gas emission level in 2012 was ranked 12th globally, despite the economy being only the $28^{\text {th }}$ largest by total gross domestic product (SALGA, 2013; Beneke et al., 2016). To spur economic growth and reverse the adverse environmental impacts of past industrialisation systems, South Africa, like other countries, has identified transition to a $G E$ as a sustainable development route that can address a myriad of economic challenges. In fact, the creation of decent work and livelihoods that are sustainable lies at the heart of South Africa's national strategy for sustainable development and action (Bek et al., 2017). As the economy becomes greener, employment will be affected in four major ways: (i) creation of additional jobs such as manufacturing pollution-control devices; (ii) technology re-orientation, such as changing from fossil fuel-based to renewable energy; (iii) job elimination; and (iv) redefinition of many jobs existing as day-to-day work procedures, profiles, and skills such as plumbing and construction (UNEP, 2009). The GE already employs many South Africans, mainly in sectors such as recycling, conservation, tourism and renewable energy. Current analysis of the potential of the unfolding GE in the country reveals the creation of approximately 98000,255 000 and 462000 direct jobs in the short, medium and long terms, respectively, in the formal economy, as shown in Table 1.

Table 1: Potential green jobs in South Africa (Maia et al. 2013).

\begin{tabular}{lccc}
\hline $\begin{array}{l}\text { Net direct } \\
\text { jobs }\end{array}$ & $\begin{array}{c}\text { Short term } \\
\text { (2012) }\end{array}$ & $\begin{array}{c}\text { Medium } \\
\text { term (2017) }\end{array}$ & $\begin{array}{c}\text { Long term } \\
\text { (2025) }\end{array}$ \\
\hline Energy generation & 13365 & 57142 & 130023 \\
Energy efficiency & 31569 & 70193 & 67979 \\
Pollution control & 8434 & 13189 & 31641 \\
Natural resources & 44512 & 114842 & 232926 \\
\hline
\end{tabular}

Local governments being closest to local businesses, job-seekers and the disadvantaged communities in local labour markets are expected to play a major role in the creation of green jobs. The local governments are, however, faced with several challenges including limited capacity and skills at the local level, that could hamper their role in job creation (Moyo, 2015). Waste management, a major mandate of municipalities, is one of the key sectors expected to facilitate the transition to a GE in South Africa. Municipalities should employ green technologies and processes in sectors such as energy and water, and with a focus on wastewater treatment. It is important for local governments to identify the skills needed for the implementation of green technologies in wastewater treatment. Creating green jobs depends not only on employing green techniques and practices in treating the waste 
deposited at the door step of the local governments. Instead, it requires proactive steps that promote green practices aimed at preventing or minimising the production of waste in the first place. To do this effectively, the municipal staff should be equipped with critical skills to manage modern infrastructure, and scientific data to help formulate policies to enhance green jobs for effective waste management (OECD, 2010).

For SA to participate in the transition to GE, there is an urgent need for sector capacity building, especially in the local government tasked with implementation of GE policies on the ground (African Centre for a Green Economy, 2015). This study was carried to analyse GE awareness and existing green jobs and to identify qualifications and skills necessary for the development of GE. This study focused on local government and small industry in the North West (NW) and Northern Cape (NC) provinces of South Africa, looking specifically at wastewater treatment (WWT).

\section{Methodology}

This study used a descriptive method, with qualitative and quantitative approaches for data collection. Surveyors carried out site visits to 24 selected WWT plants in eleven local municipalities spread across the two provinces. The 63 respondents were mostly plant managers, process controllers, and general labourers, present on-site at the times of the visits from one to five people at each site, depending on the size of the plant and staff establishment. In addition to a questionnaire with questions specific to the plant under survey, the plants were toured in order to gather information to back-up the data obtained and make adjustments where necessary, to ensure the accuracy of the data. Trends were compared across provinces, municipalities and plants, and Excel spreadsheets were generated for plotting graphs and tables. The parameters and methodologies used in assessing the green jobs were based on those reported by Nhamo (2013) and the International Labour Organisation (ILO, 2013).

A random sampling method was used to identify plants for the survey, taking into consideration the geographical location, size, and type of municipalities in order to capture comprehensive data. In each province, at least three district municipalities were selected, based on their population size and geographical location. In every district municipality selected, a further two local municipalities were selected and visited. At the local municipalities, at least two WWT plants were visited. Table 2 shows the number of field visits made.

Primary data were collected using both direct observation and semi-structured questionnaires with structured and open-ended questions. Semistructured questions were employed because of the exploratory nature of the study and because they
Table 2: Wastewater plants surveyed

\begin{tabular}{lccc}
\hline Province & $\begin{array}{c}\text { No. of district } \\
\text { municipalities }\end{array}$ & $\begin{array}{c}\text { No. of local } \\
\text { municipalities }\end{array}$ & $\begin{array}{c}\text { No. of } \\
\text { plants }\end{array}$ \\
\hline Northern Cape & 3 & 4 & 10 \\
North West & 4 & 6 & 14 \\
\hline
\end{tabular}

allow for greater flexibility in addressing unanticipated new information and obtaining more detailed information than quantitative research approaches (Pienaar et al., 2017; Makonese and Bradnum, 2006). Respondents were informed about the study and consented to participate. To support the data obtained in the investigations and to limit bias in the research process, a semi-structured in-depth interview with plant managers was conducted, based on information given. The participants could digress and introduce new topics for discussion, which allowed for exploration of concepts that were beyond the prepared questions.

\subsection{Study limitations}

Despite having been designed with the aim of accurate data-capturing and interpretation, this study was limited in the following ways:

- Bias: There were some cases of discrepancy between the information provided by operators and managers. In some cases, respondents did not provide all the required information.

- Language barrier: Some respondents were not fluent in the English language used for instruction/questioning. Furthermore, distortion in the capturing of the information could have resulted via the translation.

- Difficulty in obtaining data: It was difficult to obtain data on the exact number of existing green jobs as most municipalities did not have such records.

\section{Results and discussion}

\subsection{Classification of jobs in the surveyed plants}

The uptake of GE practices leading to green jobs creation in the wastewater sector is still very low in the two provinces. In NW and NC respectively, only $20 \%$ and a $7 \%$ of the total WWT employees were involved in direct green jobs (see Table 3). Most of the plants employed conventional activated sludge, biological nutrient removal, and oxidation pond systems of treatment. These methods mainly focused on reducing wastewater pollution load to acceptable discharge standards, with little focus on green initiatives such as wastewater reclamation for reuse and nutrient recovery, thus offering few chances for the creation of green jobs. Whereas a potential exists in utilising energy from renewable sources such as solar and biogas, the initiative to harness such energy is yet to be taken. The lack of investment in green technologies and processes, such as biodigesters for biogas recovery and com- 
post-processing units, has significantly contributed to the low number of green jobs in NW and NC.

Table 3: Demographic profile of plants visited in NW and NC provinces

\begin{tabular}{lcc}
\hline Employee occupation type & \multicolumn{2}{c}{ Percent (\%) } \\
& NW & NC \\
\hline Direct green occupation & 20 & 7 \\
Indirect green occupation & 37 & 35 \\
Occupation unrelated to green jobs & 43 & 58 \\
\hline
\end{tabular}

\subsection{Green economy awareness}

Several employees did not immediately know what green jobs are, but upon elaborate definition of green jobs by the surveyors, they could identify such jobs within several sectors such as renewable energy, transport and agriculture in NW (Figure 1) and NC (Figure 2) provinces. The concept is, however, still foreign, as evident from the several employees who still could not identify green jobs within several other sectors, even after the definition. A high percentage of employees, however, identified both waste management $(92 \%$ in $\mathrm{NW}$, $100 \%$ in NC) and water treatment $(92 \%$ in NW, $95 \%$ in NC) as the sectors most likely to have green jobs. This indicates readiness on the part of the employees towards adopting the GE in waste management. Tourism was least associated with green jobs, probably due to lack of knowledge of this sector by most employees interviewed. The foreignness of the concepts of GE and green jobs has also been observed among the wider general population. In a study on Green Rooftops Systems in South Africa, it was found that there was a lack of understanding of the advantages and construction of green rooftops amongst members of the construction sector (Labuschagne and Zulch, 2016). This low awareness could be because most governments, industries, and institutions are still grappling with the GE concept. Moreover, since there has not been a significant uptake of GE in South Africa, a substantial proportion of the population (including these interviewees) could be expected to struggle to identify green jobs and sectors. As South African municipalities respond to climate change in transitioning to the GE, all stakeholders, including plant operators, should be brought on board. This would enhance understanding and ease the transition to GE (SALGA 2013).

After the identification of sectors that could potentially create green jobs, respondents were

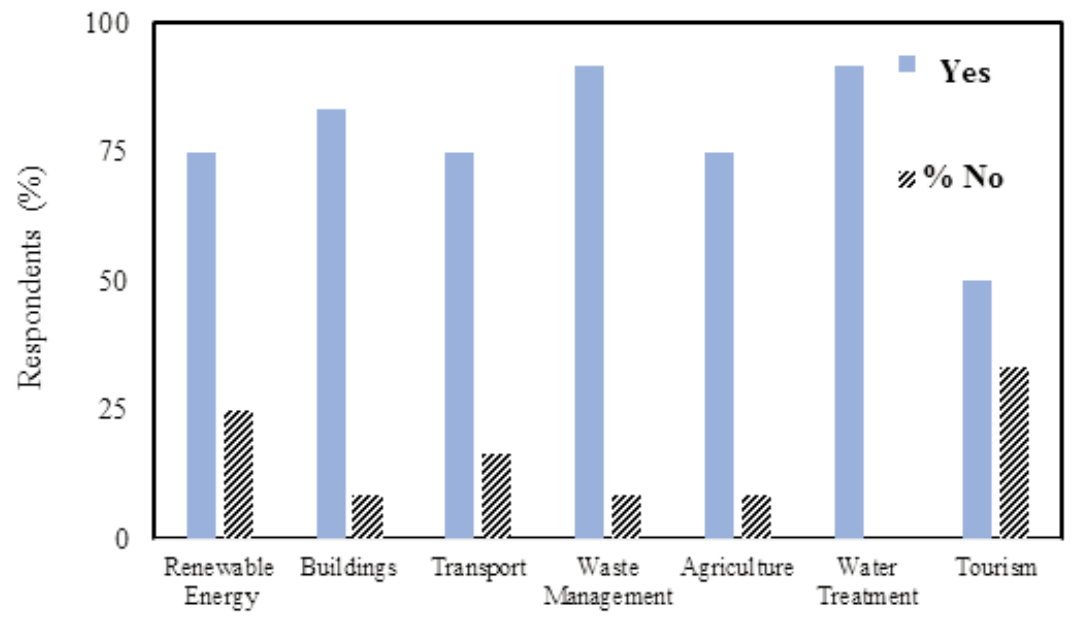

Figure 1: Sectors associated with green jobs by wastewater treatment employees in North West.

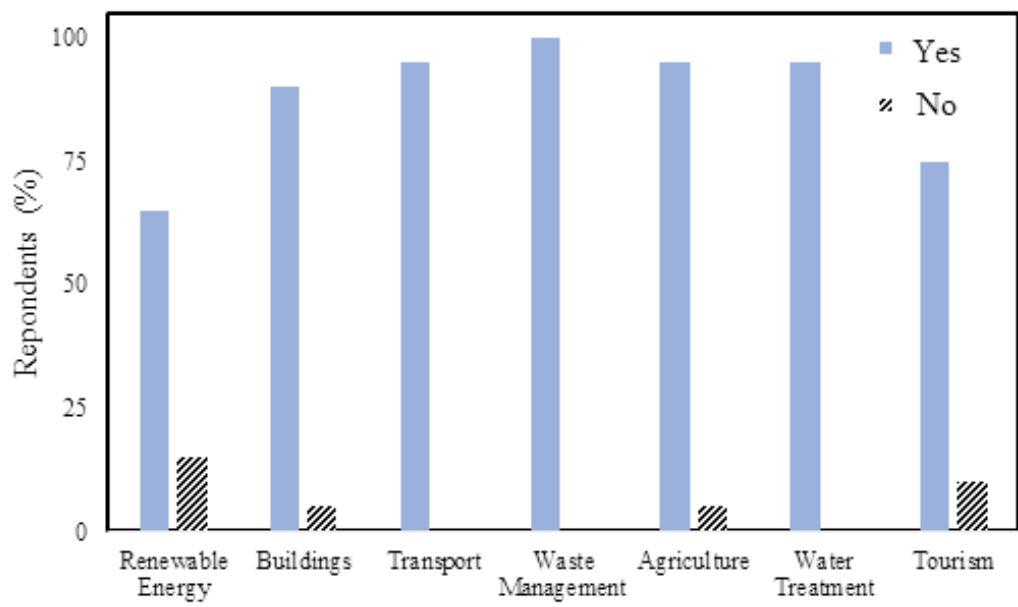

Figure 2: Sectors associated with green jobs by wastewater treatment employees in Northern Cape. 
assessed to determine their level of awareness of green jobs. Distorted responses were obtained for NW and NC as shown in Figures 3 and 4 respectively. Whereas some of the respondents could easily link green jobs with most of the sectors (Figure 2 ), the overall understanding of green jobs by all employees was limited. The concepts of GE and jobs are, as discussed above, still new and have not penetrated most industries, especially as little training on green economy and skills is offered to most employees. In NW, $75 \%$ of the respondents strongly agreed that green jobs could minimise or eliminate waste pollution. However, only $25 \%$ and $35 \%$ were convinced that green jobs could pay well and offer protection to workers' rights, respectively. Signif- icant inconsistencies were observed in responses obtained in the two provinces. While $73 \%$ of respondents in NW strongly agreed that green jobs could minimise or eliminate pollution, only $25 \%$ did so in NC. Also, in NW, $60 \%$ strongly agreed that green jobs can provide safe working conditions as compared to $10 \%$ in NC. The difference could have been influenced by the level of qualification and occupation distribution of employees in the two provinces, as shown in Table 4. Most respondents $(88 \%)$ from NW province had matriculation as the minimum formal qualification as compared to $59 \%$ in NC. Also, most of the respondents from NC consisted of general labourers (39\%), while in NW process controllers were the major respondents (34\%).

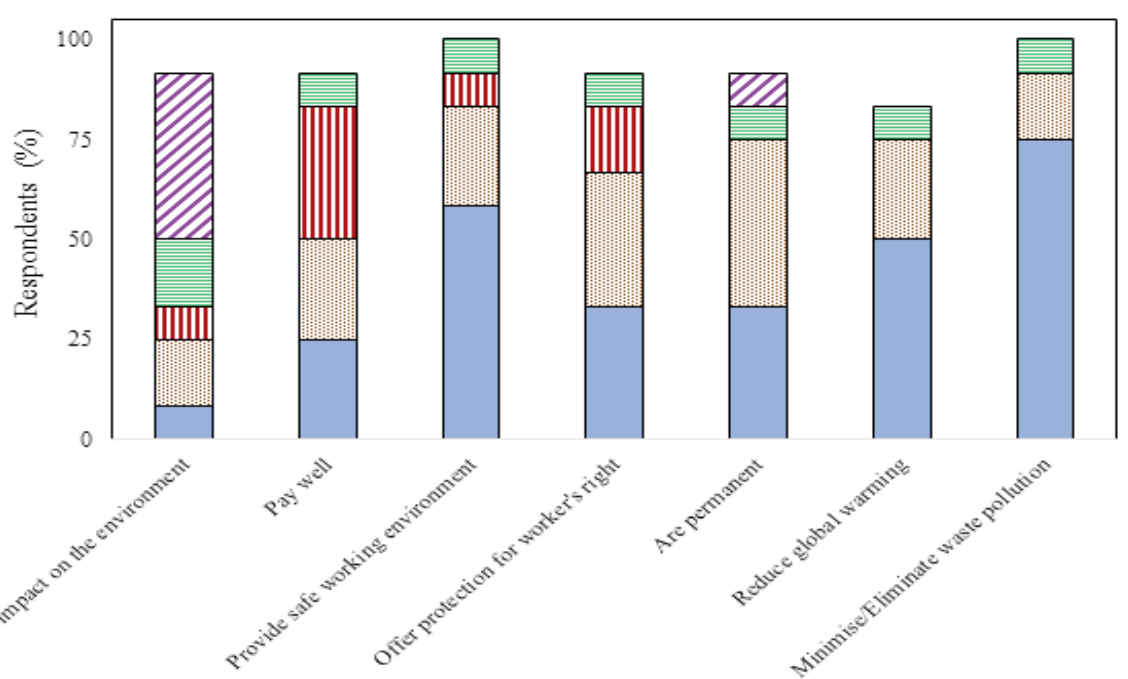

Figure 3: Green jobs awareness level in North West.
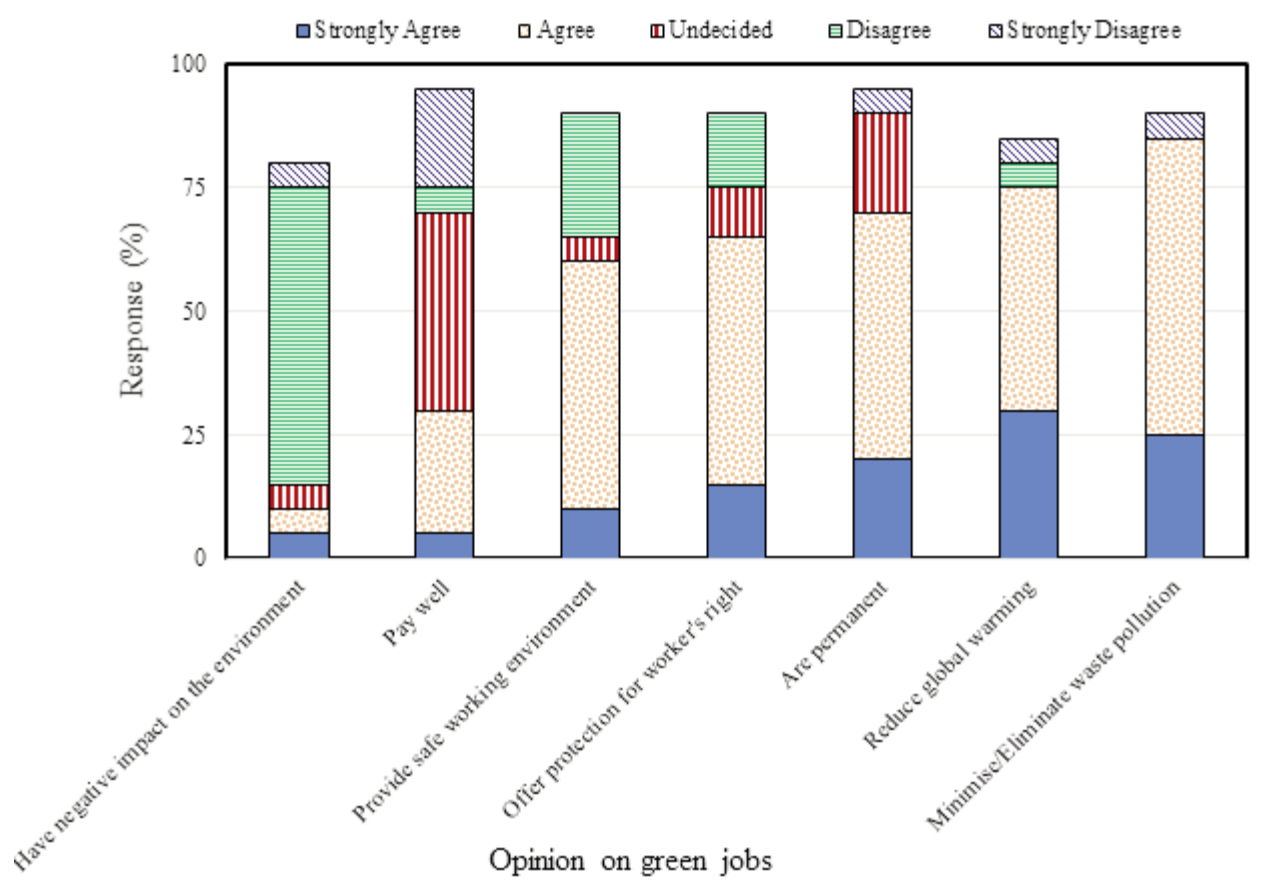

Figure 4: Green jobs' awareness level in Northern Cape. 
Table 4: Demographic profile of respondents interviewed in North West and Northern Cape

\begin{tabular}{llcc}
\hline & & $N W(\%)$ & $N C(\%)$ \\
\hline Employees' highest & Lower than matriculation & 41 & 12 \\
formal qualifications & Matriculation & 28 & 61 \\
& Certificate & 18 & 23 \\
& Diploma & 2 & 2 \\
& Degree/Postgraduate & 11 & 2 \\
\hline Occupational distribution & Plant managers & 8 & 5 \\
of respondents & Process controllers & 34 & 45 \\
& General labourers & 25 & 39 \\
& Apprentice & 25 & 6 \\
& Others (e.g. administrators) & 8 & 5 \\
\hline
\end{tabular}

The higher level of qualification and seniority of respondents in NW could have contributed to their better understanding of green jobs as compared to their counterparts in NC.

Creation of green jobs, one of the major indicators of GE, is expected to reduce environmental pollution, improve the work environment and offer decent pay (ILO, 2009). Whereas most of the respondents were aware of the positive impacts green jobs could have on the environment, there was no awareness of the positive social aspects such as decent pay with up to $33 \%$ of respondents in NW undecided on the matter. In NC, only $5 \%$ of the respondents were convinced that green jobs could pay well. Awareness should be raised with the aim of changing the mindset of the workforce. Within the context of sustainable development and dignified working conditions, GE can only be achieved if people fully embrace the idea, possess the required green skills and practically apply them (ILO 2009).

\subsection{Barriers to creation of green jobs and implementation of green practices}

A similar trend in the barriers to green jobs and practices uptake was observed for NC and NW, as shown in Figure 5. The low number of employees directly involved in green jobs was attributed to the lack of green technologies in place. Moreover, it was noted that a lack of training in green skills for the already employed operators contributes to the low uptake of green jobs. The current training in place, which is not sufficient, is only aimed at equipping the present employees with conventional skills for wastewater treatment process control, thus enabling them to attain National Qualification Framework ratings. Also, of interest is the high number of employees lacking the conventional skills, as seen by the $28 \%$ and $30 \%$ in NC and NW, respectively, who recognised shortage of skilled employees as being a barrier to uptake of green jobs. Whereas green skills are needed for effective wastewater treatment, employees should be equipped with the conventional skills as a prerequisite for training in the new green skills and technologies.
Most of the employees lacked any formal training for water and wastewater treatment and operated only on the basis of experience gained through on-the-job training under the supervision of senior operators. The lack of conventional water-care skills by most employees makes it even harder to introduce and train for green treatment systems and technologies. Since the wastewater treatment sector in the two provinces is faced with a shortage of green and conventional skills that are necessary for effective wastewater treatment, in some of the plants visited, discharge standards set for wastewater effluent were not met. The lack of green skills and knowledge also hindered transition to GE. Lack of qualified operators was attributed to poor remuneration offered by most local municipalities, leading to poor retention of skilled personnel and inability to attract experienced operators.

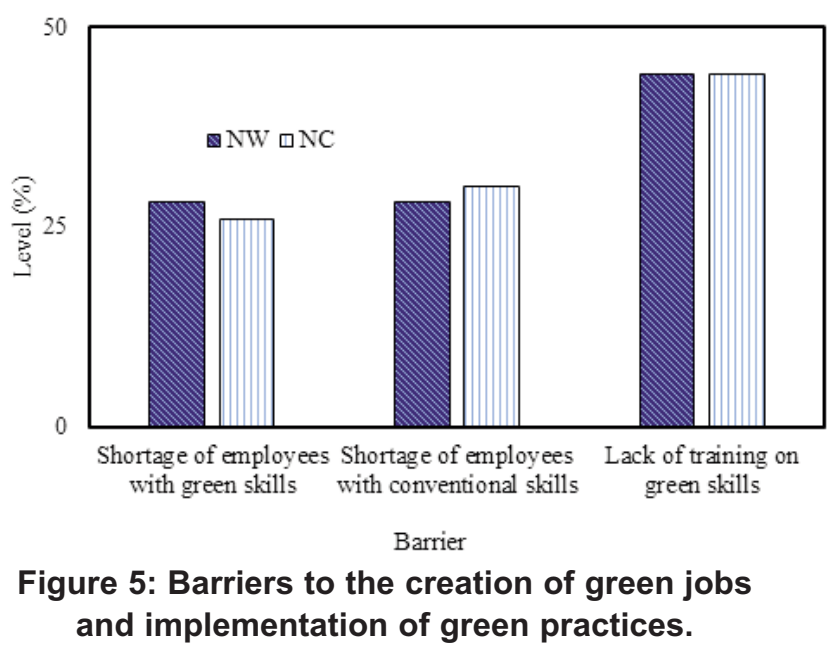

To address the skills gap, companies/municipalities could employ skilled and experienced individuals. However, the unavailability of such individuals was a hindrance to $28 \%$ of the WWT plants surveyed in NW. Understaffing was also a major challenge faced by municipalities in NC, particularly the smaller ones. Some of the plants visited had very few operators, with only a single shift of operation against the recommended two shifts or more, based 
on the size of the plants. As companies adopt green technologies, an adequate number of employees will be needed for successfully implementing and running them. It has been reported that a shortfall in managerial, professional and technical skills such as engineering and artisan, has the potential of hindering green industries' growth, thereby delaying the creation of green jobs (Sustainlabour and TIPS, 2013). Relevant new skills required for a smooth transition to green jobs include (UNEP, 2011) a good understanding of the impact of any job on the environment; knowledge of ways to contribute to a cleaner environment and reduced environmental damages at work places; and knowledge and skills on efficient resource and energy use, waste minimisation, reuse or recycling.

The new emerging green jobs require a high level of qualification and a new training system that is relevant to the emerging trends. The skill level for green jobs can be improved through initiatives including green awareness workshops offered onsite, and short-term green occupational courses in traditional universities with practical projects onsite. Moreover, training-on-the-job programmes on green skills, which should include educational training on green technologies and processes installed at the plants, should be introduced. To make the training effective and interesting, interactive smartphone-based applications that provide a personalised and customised training system should be developed. South Africa can learn from Germany, where skills response to GE in terms of training and promotion of education has been achieved. Germany has established promotion programmes, offered technical qualification and new study courses and developed further training with relevant environmental focused subjects (CEDEFOP, 2011).

\subsection{Potential for green jobs creation}

Given the low wastewater treatment capacity (treating $<5$ megalitres per day) of most of the plants surveyed, despite having domestic waste as the largest source of wastewater (see Figure 6), application of anaerobic digesters for biogas production is not feasible. However, for the few large treatment plants, anaerobic digestion of the waste activated sludge can be carried out, in the process producing bioenergy. The NW and NC provinces, being endowed with natural sources of renewable energy, such as solar with a potential averaging $8000 \mathrm{MJ} / \mathrm{m}^{2}$ per day, have the opportunity to install solar generators (solar water heaters, concentrated solar power and solar photovoltaics). Solar devices may require high initial cost of investment, but their durability and the long-term benefit of contributing to healthier and cleaner environments far outweigh the initial cost (Ferrer, 2017; Nyeinga et al., 2016). The use of renewable energy sources is likely to positively impact the future economy. Since new labour force will be required for the implementation of renewable energy, new jobs will be created as well (Karakul, 2016; Aliyu et al., 2017). Moreover, the agricultural sector could benefit from the adoption of a green treatment process by the treatment plants. Some of the potential strategies that could spur green jobs creation include reuse of treated water for irrigation of farms close to the WWT plants; conversion of sludge into dry sludge compost for use in farms and gardens; installation of anaerobic sludge digesters capable of producing biogas, which can be used to generate electricity and thus supplement energy supply; and installation of solar energy to supplement the energy

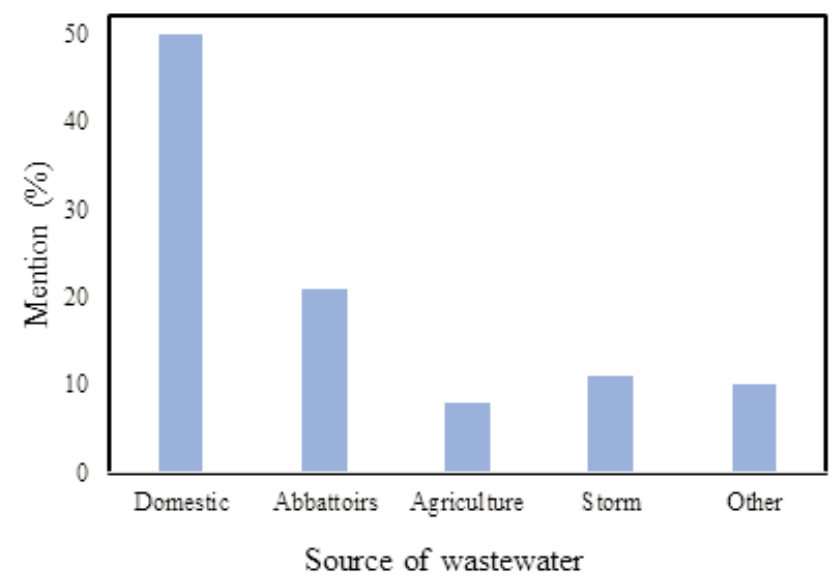

requirements of the treatment processes.

Figure 6: Sources of wastewater in the surveyed plants in North West and Northern Cape.

Considering that a lack of adequate funding is a major challenge in the WWT sector, especially for the smaller municipalities, the implementation of green technologies with high capital costs is not easily attainable. Partnership with other institutions, especially private industry, is therefore important in meeting the financial challenge (Tafadzwa, 2016). Municipalities can collaborate with industries in implementing green projects that will benefit both partners. Industries could supply the municipalities with green technologies and in turn have their waste treated by the municipalities at reduced or no costs. Partnership with training institutions is important for developing the relevant courses consistent with emerging green technologies and practices.

\section{Conclusion}

To create an adequate number of jobs, the transition to a green economy should be speeded up. North West and Northern Cape have many agricultural activities in which effluent water and sludge could be used. This could create more green jobs and encourage green practices. Also, the fact that a significant proportion of influent to wastewater plants is from abattoirs means that there is a poten- 
tial for biogas production from the wastewater. Partnership with appropriate training institutions is important in meeting the green skills required, in addition to creating green economy awareness. Since green jobs pay well, their creation will address the poor remuneration and avert the brain drain which is a major problem in many municipalities.

\section{Acknowledgement}

This work was financially supported by the Local Government Sector and Training Authority (LGSETA, Project No. SSP/Green economy occupations research/ 454/201617), South Africa.

\section{References}

African Centre for a Green Economy, (2015). Mapping the green economy landscape in South Africa http://www.sagreenfund.org.za/wordpress/wp-content/uploads/2015/04/Mapping-the-Green-Economyin-SA.pdf.

Aliyu, A.K., Modu, B. and Tan, C.W., (2017). A review of renewable energy development in Africa: A focus in South Africa, Egypt and Nigeria. Renewable and Sustainable Energy Reviews, (In press, http://dx.doi.org/10.1016/j.rser.2017.06.055).

Bek, D., Nel, E. and Binns, T., (2017). Jobs, water or conservation? Deconstructing the green economy in South Africa's Working For Water Programme. Environmental Development (http://linkinghub.elsevier.com/retrieve/pii/S2211464517300842).

Beneke, L.W., Fourie, C.J.S. and Huan, Z., (2016). Investigation of an octagon-shaped chimney solar power plant. Journal of Energy in Southern Africa, 27 (4), 38-52.

Cai, W., Wang, C., Chen, J., Wang, S., Dulal, H.B. Dulal, R., Yadav, P.K., Fankhauser, S., Gennaioli, C., Collins, M., Gibbs, D., O’Neill, K., Lazzat, Y., Aigerim, O., Daniya, N., Lindman, Å., Söderholm, P., Mundaca, L., Román, R., et al., (2015). Modelling the transition towards a green economy in South Africa. Applied Energy, 116 (June), 52-61.

Consoli, D., Marin, G., Marzucchi, A. and Vona, F., (2016). Do green jobs differ from non-green jobs in terms of skills and human capital? Research Policy, 45 (5), 1046-1060. DOI

$10.1016 /$ j.respol.2016.02.007

Death, C., (2011). 'Greening' the 2010 FIFA World Cup: Environmental Sustainability and the MegaEvent in South Africa. Journal of Environmental Policy \& Planning, 13 (2), 99-117.

European Centre for the development of Vocational Training (CEDEFOP), (2011). Skills for green jobs Country report Germany, http://www.ilo.org/ wcmsp5/groups/public/—-ed_emp/—-ifp_skills/documents/publication/wcms_142480.pdf

Friedrich Ferrer, P.A., (2017). Average economic performance of solar water heaters for low density dwellings across South Africa. Renewable and Sustainable Energy Reviews, 76, 507-515.
International Labour Organisation (ILO), (2013). Methodologies for assessing green jobs, http://www .ilo.org/wcmsp5/groups/public/_-ed_emp/—emp ent/documents/publication/wcms 176462.pdf\& usg $=$ AFQjCNHACJ4q3YEbMFaMpfJSfhwE1NDeNA $\& \operatorname{sig} 2=c$.

Kaggwa, M., Savious, S. and Nhamo, G., (2013). South Africa's green economy transition: Implications for reorienting the economy towards a low-carbon growth trajectory. South African Institute of International Affairs Occasional Paper No 168.

Kayahan Karakul, A., (2016). Educating labour force for a green economy and renewable energy jobs in Turkey: A quantitave approach. Renewable and Sustainable Energy Reviews, 63, 568-578.

Labuschagne, P. and Zulch, B., (2016). Green Rooftop Systems: A South African Perspective. Energy Procedia, 96, 710-716.

Loiseau, E., Saikku, L., Antikainen, R., Droste, N., Hansjürgens, B., Pitkänen, K., Leskinen, P., Kuikman, P. and Thomsen, M., (2016). Green economy and related concepts: An overview. Journal of Cleaner Production, 139, 361-371.

Lyon, A., Hunter-Jones, P. and Warnaby, G., (2017). Are we any closer to sustainable development? Listening to active stakeholder discourses of tourism development in the Waterberg Biosphere Reserve, South Africa. Tourism Management, 61, 234-247.

Maia, J.; Giordano, T.; Kelder, N.; Bardien, G.; Bodibe, M.; Du Plooy, P.; Jafta, X.; Jarvis, D.; Kruger-Cloete, E.; Kuhn, G.; Lepelle, R.; Makaulule. L.; Mosoma, K.; Neoh, S.; Netshitomboni, N.; Ngozo, T.; Swanepoel, J., (2013). Green Jobs: An estimate of the direct employment potential of a Greening South African economy. South African Journal of Science, 109 (9), 1-4

Makonese, T. and Bradnum, C.M.S., (2006). Public participation in technological innovation: The case of the Tshulu stove development programme. Journal of Energy in Southern Africa, 28 (1), 13-24.

Moyo, T., (2015). Local government and green jobs creation: exploring opportunities in selected metropolitan municipalities in South Africa. Journal of Public Administration, 50 (1), 70-89.

Musango, J.K., Brent, A.C. and Bassi, A.M., (2014). Modelling the transition towards a green economy in South Africa. Technological Forecasting and Social Change, 87, 257-273.

Nhamo, G., (2013). Green economy readiness in South Africa: A focus on the national sphere of government. International Journal of African Renaissance Studies - Multi-, Inter- and Transdisciplinarity, 8 (1), 115-142.

Nyeinga, K., Nydal, O.J., Okello, D. and Banda, E.J.K.B., (2016). Dynamic model of a small scale concentrating solar cooker with rock bed heat storage. Journal of Energy in Southern Africa, 27 (1), 20-27.

Organisation for Economic Co-operation and Development (OECD), (2010). Green jobs and skills: the local labour market implications of addressing climate change, http://www.oecd.org/dataoecd/ 54/43/44683169.pdf. 
Pienaar, E.F., Rubino, E.C., Saayman, M. and van der Merwe, P., (2017). Attaining sustainable use on private game ranching lands in South Africa. Land Use Policy, 65 (October 2016), 176-185.

Shava, E. and Tafadzwa Clementine, M., (2016). A Descriptive Analysis of the Causes, Challenges and Effects of Skills Deficit on Youth Empowerment in South Africa. Journal of Social Sciences, 49 (12), 93-100.

South African Local Government Association (SALGA), (2013). The green economy. LED news, 9.

Sustainlabour and TIPS, (2013). Green jobs and related policy frameworks: An overview of South Africa, http://www.tips.org.za/files/green_jobs_and_related_p olicy_frameworks_-_overview_south_africa.pdf.

Tafadzwa Clementine, M., (2016). Towards The Implementation of Public-Private- Partnerships (PPPs) for Efficient Service Delivery in Public Institutions in South Africa. Journal of Human Ecology, 54 (2), 119-123.

Topgül, S., (2015). A solution for unemployment: Green jobs and green employment. International Journal of Human Sciences, 12 (2), 1334.

United Nations Environmental Programme (UNEP), (2009). Green Jobs: Towards decent work in a sustainable, low-carbon world, www.unep.org/civil_society/Publications/index.asp.

United Nations Environmental Programme (UNEP), (2011). Towards a green economy: Pathways to sustainable development and poverty eradication. DOI 10.1063/1.3159605.

Winkler, H. and Marquand, A., (2009). Changing development paths: From an energy-intensive to low-carbon economy in South Africa. Climate and Development, 1 (1), 47-65.

Yi, H., (2013). Clean energy policies and green jobs: An evaluation of green jobs in U.S. metropolitan areas. Energy Policy, 56, 644-652. 